\title{
O CONCEITO DE TERRITÓRIO E O FETICHISMO DO PODER
}

\author{
THE CONCEPT OF TERRITORY AND THE FETISHISM OF POWER
}

\section{EL CONCEPTO DE TERRITORIO Y EL FETICHISMO DEL PODER}

\author{
Lucas Maia \\ Mestre em Geografia pela Universidade Federal de Goiás \\ Professor da Universidade Estadual de Goiás - UnU/Minaçu. \\ Rua transamazônica, Qd. 88, Lt. 15 \\ Cidade Livre / Aparecida de Goiânia - GO \\ CEP: 74970-360 \\ Email: maiaslucas@yahoo.com.br
}

\section{Resumo}

Este texto faz uma reflexão acerca da relação existente entre os conceitos de território e poder. Faz inicialmente uma discussão apresentando como o conjunto dos autores que se dedicaram à discussão do conceito de território o vêem como uma emanação do poder. Não existe, na leitura destes autores, formas de constituição de territórios que não sejam mediadas pelo poder. Denominamos esta interpretação de fetichismo do poder. O fetichismo consiste na perca por parte dos sujeitos tanto do controle sobre suas ações quanto da perda de controle sobre os produtos de sua criação. Na consciência fetichista, os produtos passam a ser os criadores. Para superar o fetichismo do poder, sugerimos a distinção entre territórios autoritários (mediados pelo poder) e territórios libertários (mediados pelo coletivismo, solidariedade e igualdade concreta). Constatamos que os territórios autoritários são banais em nossa sociedade ao passo que os libertários só se constituem em momentos de contestação da sociedade capitalista. Demonstramos que a relação entre poder e território não pode ser compreendida como unívoca ou necessária, mas tão somente como histórica e transitória. Da mesma forma que foi produzida historicamente, pode e deve ser superada com o desenrolar histórico das sociedades humanas.

Palavras-Chave: Território, poder, fetichismo.

\begin{abstract}
This paper depicts the relationship between the concepts of territory and power. Initially we presented the authors who have devoted themselves to discussing the concept of territory, which seems to be an emanation of power. We understand such interpretation as fetishism of power. Fetishism can be defined as the loss by individuals of their control over the actions and the products of their creation. In fetishistic consciousness the products become the creators. To overcome the fetishism of power, we distinguish between authoritarian areas (mediated by power) and libertarian territories (mediated by
\end{abstract}


collectivism, solidarity and equality). We found that the authoritarian territories are normally trivial in our society while libertarians only exist in times of challenge to the capitalist society. We also demonstrated that the relationship between power and territory can not be understood as unequivocal or necessary, but only as historical and transitory. In the same way it was produced historically, it can be overcome throughout the history.

Keywords: Territory; Power; Fetishism.

\section{Resumen}

Este artículo reflexiona sobre la relación existente entre los conceptos de territorio y poder. Inicialmente presentado como una discussión de todos los autores que se han dedidicado a debatir el concepto de territorio que lo vem como una emanación del poder. No existe, en la lectura de estos autores, las formas de constituición de territorios que no están mediadas por el poder. Llamamos esta interpretación de fetichismo del poder. El fetichismo es perder por las personas tanto de control sobre sus acciones y la pérdida de control sobre los productos de su creación. En la conciencia fetichista, los productos se convierten en creadores. Para superar el fetichismo del poder, proponemos la distinción entre territorios autoritarios (mediada por el poder) y territorios de los libertarios (mediada por el colectivismo, la solidaridad y la igualdad concreta). Se encontró que los territorios autoritários son corrientes banales en nuestra sociedad, mientras que los libertarios están sólo en tiempos de desafío a la sociedad capitalista. Demostramos que la relación entre poder y territorio no puede ser entendida como inequívoca o necesario, pero sólo como histórica y transitoria. Así como fue producido históricamente se pueden superar con la historia de desarrollo de las sociedades humanas.

Palabras-clave: Territorio; Poder; Fetichismo.

\section{Introdução}

Este texto visa apresentar uma discussão acerca do conceito de território. Nosso intento é apresentar uma leitura crítica no que concerne à relação entre território e poder. Os autores que comumente se dedicam à discussão do conceito de território nunca prescindem do conceito de poder. Isto, entretanto, não é um problema em si. A grande questão é que o poder é tomado como sendo algo dado, necessário, intrínseco ao ser humano e às relações sociais. Este é o problema central.

Nosso objetivo é demonstrar como esta idéia é ideológica, ou seja, uma falsa consciência sistematizada; uma inversão da realidade expressa numa linguagem complexa, científica. A naturalização do poder e a vinculação deste com o território impede que se analise a própria natureza territorial de determinadas relações sociais. 
Para iniciar nossa discussão, questionamos: como território e poder são analisados pelo conjunto dos autores que se dedicaram de uma ou outra maneira a este debate? É o poder tratado de maneira fetichista pelos autores? Em quais experiências históricas podemos encontrar relações sociais que não mediatizam o território pela via do poder?

Responderemos estes questionamentos apresentando inicialmente a relação entre poder e território presente nas análises de alguns autores que discutem o território de um ponto de vista conceitual. Em seguida, discutiremos o conceito de poder, demonstrando como ele foi abordado, historicamente, de maneira fetichista. Por último, analisaremos um conjunto de características e princípios que julgamos fundamental para compreender o território além do poder.

\section{Território e Poder: Irmãos Siameses}

O território sempre esteve vinculado ao poder, ou melhor, o território só pode existir por meio deste. Esta é a assertiva mais comum dentro dos estudos territoriais. Desde $O$ Príncipe de Machiavel, passando por Ratzel, pela geopolítica o poder sempre foi entendido como manifestação do poder estatal. Após as pesquisas de Michel Foucault, que passam a considerar o poder como sendo um poder relacional, o poder está presente em todo e qualquer tipo de relação, não ficando assim, restrito à idéia de poder como uma emanação do estado. Esta concepção vai exercer grande influência dentro dos estudos territoriais, modificando consideravelmente o entendimento acerca da relação existente entre poder e território. O estado perde o monopólio do território e do poder. Outros grupos passam a ser compreendidos como agentes territorializados. Acompanhemos detidamente estas metamorfoses no conceito de território.

Ratzel é sem sombra de dúvidas um dos principais autores que dedicou grande parte de sua análise à compreensão da realidade, do homem e da sociedade de um ponto de vista territorial. Sua Antropogeografia e sua Geografia Política são clássicos no entendimento e discussão da sociedade de um ponto de vista geográfico. Nossa intenção aqui não é fazer uma análise da totalidade da obra deste autor ${ }^{1}$, mas tão somente evidenciar como ele abordava a relação território e poder. Ratzel foi um autor 
conservador, ou seja, produziu suas ideologias expressando claramente a política expansionista do governo de Bismark no final século 19, na Alemanha. Foi um ardoroso defensor da ideologia positivista, sendo sua obra pioneira na introdução do positivismo na ciência geográfica, Ratzel buscou apresentar um conjunto de teorizações e análises empíricas nas quais procurava encontrar os nexos explicativos na relação terra (solo, natureza...)/sociedade.

Sua distinção entre povos "naturais" e "civilizados" se dava pelo desenvolvimento ou não da instituição estatal. Os povos civilizados eram aqueles nos quais o estado já estava em pleno gozo. Criticando a ciência política de seu tempo, afirma:

Que o território seja necessário à existência do estado é coisa óbvia. Exatamente porque não é possível conceber um estado sem território e sem fronteiras é que vem se desenvolvendo rapidamente a geografia política; e embora mesmo a ciência política tenha frequentemente ignorado as relações de espaço e a posição geográfica, uma teoria de estado que fizesse abstração do território não poderia jamais, contudo, ter qualquer fundamento seguro (Ratzel, 1990, p. 73).

Ou seja, estado e território são necessariamente interdependentes, um completa o outro. A ciência política até seu tempo negligenciou este aspecto, por isto ele cunha a idéia de geografia política, ou seja, a dimensão territorial, geográfica da política, do estado, do poder estatal. O estado tem a função de proteger "o território contra as violações vindas de fora que poderiam reduzi-lo" (Ratzel, 1990, p. 76). Ratzel compreende bem que há sociedades que não tem estado. Embora estas mantenham um vínculo orgânico com seu solo/terra, não podem constituir território, visto que este é do campo político; e somente sociedades organizadas em estados fazem política. A sociedade se organiza em estado quando visa manter seu território. "A sociedade que consideramos, seja grande ou pequena, desejará sempre manter sobretudo a posse do território sobre o qual e graças ao qual ela vive. Quando esta sociedade se organiza com esse objetivo, ela se transforma em estado" (Ratzel, 1990, p. 76).

O estado, entendido como uma tendência natural do desenvolvimento humano, é par excelence o sujeito ativo da produção do território. Com a função de proteger e fazer desenvolver o corpo social, o estado é o organismo necessário para

\footnotetext{
${ }^{1}$ Para uma discussão aprofundada sobre a obra de Ratzel Cf. Moraes (1988; 1990), Raffestin (1993), Moreira (1992), Gomes (1996) entre outros.
} 
tanto. O incremento e ampliação do território é uma "tarefa" do estado, pois procedendo assim fortalece-se a si mesmo, visto que uma unidade com o território. Da maneira como Ratzel expõe o raciocínio, fica patente sua vinculação do território com o poder estatal e este como única fonte de poder. O estado se configura como tal exercendo seu poder sobre um dado território, portanto sobre a população e recursos deste território.

É contra esta idéia seminal que Raffestin (1993) escreve sua obra muito citada: Por uma Geografia do Poder. O título da obra já é por demais sugestivo. Tratase de colocar o debate em torno do poder como elemento central do discurso geográfico. No bojo da revisão crítica pelo qual passava a geografia nos anos de 1960/1970, esta obra, publicada em 1980, é de indiscutível importância neste sentido. No que concerne à relação entre poder e território, sua opinião é bastante clara. Tal como argumentava Ratzel e toda a geopolítica ${ }^{2}$ posterior a Ratzel, o território é fruto do poder sobre uma dada parcela da superfície terrestre. A maneira como tal poder é exercido, quem o exerce etc. é variável de autor para autor, de concepção para concepção. Mas há unanimidade em constatar que o território não existe sem a mediação do poder.

Raffestin dirige uma crítica ampla à geopolítica e geografia política clássicas, as quais denominou com razão de "geografia do estado". O centro de sua crítica reside no fato de estas identificarem as relações de poder e seus processos de territorialização com a instituição estatal. O estado, na concepção da geopolítica e geografia política clássicas é o detentor unívoco e inquestionável do poder. Afirma:

A partir do momento em que o estado = político, a categoria do poder estatal sendo superior a todas as outras, o estado pode vir a ser a única categoria de análise. Dizer que o estado é a única fonte do poder é, como dissemos, uma confusão, mas também um discurso metonímico. Ou o estado detém o poder e é o único a detê-lo; ou é o poder superior e é preciso construir a hipótese de poderes inferiores (Raffestin, 1993, p. 16).

Claro está que para o autor, o território não se restringe ao estado-nação, ao território estatal e, por conseguinte, o poder não é uma exclusividade do estado, existindo outros grupos sociais capazes de exercê-lo contra o estado ou com o estado. Nisto, Raffestin se distancia da geografia e geopolítica clássicas.

Para ele: 
É essencial compreender bem que o espaço é anterior ao território. O território se forma a partir do espaço (...). O território, nesta perspectiva é um espaço onde se projetou um trabalho, seja energia e informação, e que, por conseqüência, revela relações marcadas pelo poder. O espaço é a "prisão original", o território é a prisão que os homens constroem para si (Raffestin, 1993, p. 143/144).

Tal como observam Saquet (2007) e Souza (2003), a concepção de espaço apresentada por Raffestin é bastante problemática na medida em que o reduz a substrato das ações humanas. Mais ainda, o entende como anteparo natural. Na sua concepção, espaço seria equivalente de natural e território, de espaço social. Como observa Souza (2003), o não entendimento do caráter distinto do território, ou seja, de que este não se confunde com o espaço, embora só possa existir em inteira correlação com este, levou Raffestin a produzir tal equívoco. Se acertou no entendimento que o território não se restringe à ação estatal, equivocou-se quando não estabeleceu claramente a distinção entre espaço e território.

Sobre este aspecto, criticando Raffestin, Souza assim o diz:

Essa materialização do território é tanto mais lamentável quando se tem em mente que Raffestin pretendeu desenvolver uma abordagem relacional adequada à sua Geografia do poder, entendida de modo frutiferamente mais abrangente do que como uma Geografia do estado. Ao que parece, Raffestin não explorou suficientemente o veio oferecido por uma abordagem relacional, pois não discerniu que o território não é o substrato, o espaço social em si, mas sim um campo de forças, as relações de poder espacialmente delimitadas e operando, destarte, sobre um substrato referencial (Souza, 2003, p. 97) (grifos no original).

Esta abordagem supera as anteriores, pois esclarece e delimita melhor o uso do conceito de território. Vimos que de Ratzel a Raffestin há um avanço na construção do conceito, na medida em que é retirado do estado o monopólio no exercício do poder e portanto na construção da territorialidade. De Raffestin a Souza, há um novo salto qualitativo, quando o conceito é melhor precisado, ou seja, é clarificada sua diferença com o conceito de espaço (geográfico, social etc. $)^{3}$.

\footnotetext{
${ }^{2}$ Para uma discussão mais aprofundada sobre a geopolítica, sua vinculação com o imperialismo e por conseguinte, da sua como relação o poder/estado/território Cf. Becker (2003); Sodré (1986) etc.

${ }^{3}$ Para uma abordagem mais abrangente das várias interpretações e concepções sobre o conceito de território Cf. Saquet (2007). Nesta obra o autor faz uma "varredura" das várias interpretações acerca do conceito de território que predominam nos Estados Unidos, França, Itália e Brasil. Naturalmente que os autores interpretados exercem influência em outros países, mas são estes os destacados pelo autor.
} 
Mas o que é comum a todas estas concepções é a relação entre poder e território. São, na ciência política, na geografia política e geopolítica e nos estudos territoriais em geral, irmãos siameses. Um não é apresentado sem o outro. O território é sempre mediado pelo poder. Seja o poder do estado como em Ratzel, o poder do estado e de outros grupos como em Raffestin, Souza e vários outros, o território é sempre definido em relação a este.

Desta constatação deriva um problema de difícil solução: para que os autores apresentados estejam corretos em sua leitura acerca da relação poder/território, tem-se que admitir que o poder é uma relação natural, pois faz a mediação de todas as sociedade humanas entre si e com o espaço. Se pelo contrário, admitimos que o poder é uma relação social e que portanto pode ser abolida, ou seja, não é intrínseco ao ser humano, temos de considerar que os autores que abordaram o território como sendo uma emanação do poder estão equivocados.

Lançaremos agora uma hipótese que esperamos seja confirmada na última seção deste artigo. Partimos do pré-suposto que o poder não é intrínseco ao ser humano, mas sim uma relação social histórica e concretamente determinada. Deste modo, se os autores anteriormente analisados estão corretos ao afirmarem que a constituição do território é uma necessidade humana, ou melhor, as sociedades só se constituem se territorializando, somos obrigados a afirmar que se equivocaram ao identificar o território com o poder.

Acreditamos que o território é sim um conjunto de relações sociais referenciadas no espaço, ou seja, território e espaço não se confundem. O que distingue nossa concepção das anteriores é a maneira como é abordado o poder. De nossa parte, defendemos que tais relações sociais referenciadas no espaço, podem ou não ser mediadas pelo poder. Diante disto, propomos os conceitos de territórios autoritários, quando mediados pelo poder e territórios libertários, quando mediados por outras relações sociais, tais como solidariedade, cumplicidade, igualdade concreta etc. Os territórios autoritários são empiricamente verificáveis, ou seja, são banais, constituem a nossa sociedade. Os territórios libertários, pelo contrário, são uma tendência e se manifestam em momentos históricos determinados, como veremos posteriormente. 
Diante disto, questionamos: o que é o poder? É possível o estabelecimento de relações sociais que não sejam mediadas pelo poder? Qual o conteúdo e a forma destas relações? Estes são os problemas que buscaremos resolver em seguida.

\section{Para uma Crítica ao Fetichismo do Poder}

Nossa intenção aqui não é apresentar uma leitura histórica das várias concepções de poder. Também não faremos uma antologia do maior número de definições possível e existente até o momento. Esta é uma tarefa que as dimensões de nosso trabalho não permitem executar. Apresentaremos somente uma concepção, a qual consideramos adequada para uma leitura abrangente da discussão que estamos colocando agora em pauta.

Como dissemos, o poder não é intrínseco ao ser humano. É uma relação social estabelecida concretamente entre dois ou mais sujeitos que se relacionam. Tal relação implica em processos de dominação. O poder é desta maneira uma relação de dominação. Implica sempre numa ação exterior de um sujeito (indivíduo, grupo, classe social etc.) sobre outro.

Vasquez (1975), tratando de tema diferente, ou seja, moral e condições para a decisão moral dos indivíduos, nos dá uma boa apresentação de como o poder se manifesta através de uma ação de um indivíduo, grupo ou classe social sobre um indivíduo, grupo ou classe social:

Quando o agente moral está sob a pressão de uma coação externa, perde o controle dos seus atos, sendo-lhe fechado o caminho da eleição e da decisão pessoais, razão pela qual realiza um ato nem escolhido nem decidido pessoalmente. Na medida em que a causa do ato está fora do agente, escapando ao seu poder e controle, e em que se lhe barra a possibilidade de decidir e agir de outra maneira, não se pode responsabilizá-lo pelo modo como agiu (Vasquez, 1975, p. 96) (grifos nossos).

O que é importante extrair desta citação é o que caracteriza de maneira mais clara uma relação mediada pelo poder, ou seja, a subordinação de um sujeito pelo outro. Viana (2003) apresenta uma passagem lapidar para uma definição concreta do conceito de poder:

O poder só pode ser compreendido como relação de dominação, o que implica a existência de dominantes e dominados. Entretanto, essa relação 
entre dominantes e dominados não pode ser compreendida como uma relação entre "iguais" como dá a entender Foucault. Existe uma mediação nessa relação. Entre o dominante e o dominado existe a detenção do poder pelo primeiro (Viana, 2003, p. 14).

Realizando uma crítica às concepções de Michel Foucault, Viana fornece uma definição acerca do conceito de poder que consideramos superar as limitações que permearam o debate até então. Foucault, como é sabido, defende claramente a idéia de que o poder não pode ser possuído por ninguém, pois "poder é relação". Se o poder é relação, logo ele está em tudo, se manifesta em tudo. Assim, não pode ser atributo de um sujeito específico, visto que é uma ação relacional. Isto pode ser visto na seguinte passagem de Vigiar e Punir:

Ora, o estudo desta microfísica supõe que o poder nela exercido não seja concebido como uma propriedade, mas como uma estratégia, que seus efeitos de dominação não sejam atribuídos a uma "apropriação", mas a disposições, a manobras, a táticas, a técnicas, a funcionamentos. (...) Temos em suma que admitir que esse poder se exerce mais que se possui, que não é o "privilégio" adquirido ou conservado da classe dominante, mas o efeito do conjunto de suas posições estratégicas - efeito manifestado e às vezes reconduzido pela posição dos que são dominados (Foucault, 1975, p: 29).

Claro está o posicionamento distinto de ambas as concepções. A de Foucault retira do ser humano a "responsabilidade" no exercício do poder, retira-lhe o status de agente do poder, visto que o dilui na idéia de "relação", "estratégia", "tática", "manobras" etc. O poder é fruto disto e não uma ação concreta de dominação de um sujeito sobre outro. O mérito de Foucault foi o de retirar do estado o monopólio sobre o exercício do poder. A ciência política clássica tomava esta instituição como a única capaz de exercer, de colocar em prática relações de poder. O problema é que Foucault diluiu tanto o poder que o tornou uma substância homeopática, dispersa em estratégias, táticas e relações...

O Príncipe de Machiavel, O Leviatan de Hobbes, a Geografia Política de Ratzel, as ideologias geopolíticas de Halford Mackinder, Rudolf Kjellén, Karl Haushofer ${ }^{4}$ etc. são uma expressão clara da concepção segundo a qual o poder é restrito à instituição estatal. Foucault teve o mérito de reconhecer que existe uma "microfísica do poder", estendendo este suas teias por outras relações e instituições que não

\footnotetext{
${ }^{4}$ Para uma discussão das várias interpretações destes autores Cf. Sodré (1986).
} 
unicamente o estado. Raffestin (1993), seguindo a esteira de Foucault, desenvolveu uma leitura territorial do poder, demonstrando as implicações geográficas da concepção foucaultiana de poder.

Se as concepções que restringem o poder e o território ao estado não compreendem as várias dimensões e escalas que estes assumem, aqueles que lhes retiram o monopólio não compreendem que o poder é um tipo de relação entre os seres humanos. Não é o único, nem é eterno. Esta afirmação implica em considerar que as relações sociais entre os seres humanos podem ser mediadas por relações de poder (sendo relações de dominação e exploração) e/ou podem ser relações fundadas na igualdade concreta entre os seres humanos, em relações de solidariedade, fraternidade entre grupos, comunidades etc. No que concerne à constituição de territórios, as primeiras conformam os territórios autoritários, as segundas, os territórios libertários.

Entendemos que, quando as relações de poder não são colocadas em suas condições concretas de existência, ou seja, dentro das relações de dominação, que são historicamente e socialmente determinadas, o poder se torna um fetiche. Fetichismo, para nós tem um sentido bem preciso e profundo. Trata-se de um conceito que expressa processos sociais concretos e determinados no tempo e no espaço. O fetiche é a completa coisificação dos seres humanos, é o conceito que explica o processo de transformação dos seres humanos em produtos de suas próprias criações.

Marx, analisando o processo de produção de mercadorias na sociedade capitalista, identifica que no seio do processo produtivo está o cerne da fetichização que reina absoluta na sociedade moderna. Discutindo o caráter fetichista da mercadoria afirma:

O misterioso da forma mercadoria consiste, portanto, simplesmente no fato de que ela reflete aos homens as características sociais do seu próprio trabalho como características objetivas dos próprios produtos de trabalho, como propriedades naturais sociais dessas coisas e, por isso, também reflete a relação social dos produtores com o trabalho total como uma relação social existente fora deles, entre objetos. (...) Assim, no mundo das mercadorias, acontece com os produtos da mão humana. Isso eu chamo o fetichismo que adere aos produtos de trabalho, tão logo são produzidos como mercadorias, e que, é inseparável da produção de mercadorias (Marx, 1988, p. 71).

A mercadoria é tomada neste texto como a expressão mais genuína do fetichismo. Produto de relações sociais concretas, a mercadoria oculta o conteúdo destas 
relações. O trabalhador que a produz, maravilha-se com o produto de seu trabalho na vitrine perguntando-se: "quem será capaz de produzir tal coisa?", "Como tal produto pode ser produzido?” etc. O fetichismo é a perda do controle dos indivíduos concretos sobre as relações sociais das quais ele é partícipe no processo de produção e reprodução. O fetichismo é, portanto, o processo de ocultamento que impede a compreensão dos processos sociais de produção dos produtos (produção num sentido amplo: mercadorias, relações, instituições, arte, espaço, território, poder etc.). A consciência fetichista maravilha-se diante do gigantismo e autonomia dos produtos de sua própria criação.

Marx define a essência do fetichismo da seguinte forma: "Seu próprio movimento social possui para eles [os produtores] a forma de um movimento de coisas, sob cujo controle se encontram, em vez de controlá-las" (Marx, 1988, p. 72/73). Ou seja, os seres humanos produzem as relações que os dominam e julgam que estas são independentes e autônomas, não podem fazer nada contra elas, pois são dadas, naturais, universais, eternas, divinas ou qualquer outra coisa deste gênero. A consciência fetichista só vê o movimento como movimento de coisas relacionando-se entre coisas. Assim, o milho troca-se com o arroz e não o produtor ou mercador de milho troca com o produtor ou mercador de arroz. Eis o que é a consciência fetichista: impotente diante de suas criações.

Diante do que expusemos até agora, podemos afirmar cabalmente que o poder é entendido de maneira fetichista pelos autores. Tanto aqueles que vêem o poder somente no estado, quanto aqueles que o diluem no interior da sociedade (Foucault e seus epígonos) entendem o poder como algo dado, ou seja, não pode ser abolido, visto que é o cerne das ações humanas. O poder é uma relação social que se torna um produto que oculta o real entendimento das relações que o geram. O operário fica deslumbrado com o carro que ajudou a produzir estampado na vitrine. Os ideólogos que se dedicam ao estudo do poder e do território gozam com os construtos em torno do poder e não compreendem a natureza das relações que o produziram. $\mathrm{O}$ operário tem na mercadoria o produto que oculta as relações que o exploram e o oprimem cotidianamente. O ideólogo tem nos construtos (fetiches) os produtos acabados que os impedem de compreender a essência das relações sociais. Assim, o poder, de conceito explicativo da realidade, passa a ser um grande fetiche que impede a compreensão ou dá 
uma explicação falsa sobre o mundo. Eis como se debatem, como peixes fora d'água, os ideólogos do poder.

\section{Poder e Contra-Poder: Territórios Autoritários e Territórios Libertários}

O poder se tornou um grande construto ${ }^{5}$ ideológico. Por conseguinte, seu irmão siamês, o território, também. Como vimos, um não é entendido sem o outro. É necessário uma cirurgia para separamos estes irmãos. Enquanto continuarem unidos pelas vísceras, poder e território nunca deixarão de ser construtos, ou seja, palavras complexas que expressam falsas consciências sobre a realidade. Em uma palavra, a ideologia ou se preferem, as ideologias são formas de conhecimento vinculadas a interesses de classes que visam manter o status quo.

O poder definido como monopólio do estado ou como relação (Foucault, 1983) é um construto que serviu à edificação de inúmeras ideologias. São construtos justamente por que não expressam adequadamente a realidade, visando, intencionalmente ou inintencionalmente, a reprodução do poder enquanto tal. Quando Viana (2003) o define como uma relação de dominação, que pode ser exercida em múltiplas escalas, da relação interpessoal à dominação do estado, temos aí a elaboração de um conceito, ou seja, palavra complexa que expressa a realidade. Com relação ao território, ocorre o mesmo processo. Como tradicionalmente foi compreendido como uma emanação do poder, nunca pode ser verdadeiramente compreendido, visto que o território não se resume ao poder, por isto sempre se manifestou como um construto.

A concepção mais próxima da qual defendemos é a de Souza (2003), quando afirma que “ (...) o território não é o substrato, o espaço social em si, mas sim um campo de forças, as relações de poder espacialmente delimitadas e operando, destarte, sobre um substrato referencial" (Souza, 2003, p. 97) (grifos no original). O autor consegue clarear bastante a nebulosidade que pairava sobre o termo. Entretanto, o fetiche do poder o impede de apreciar com mais precisão a complexidade que envolve o território.

\footnotetext{
5 Para Viana, um construto "é uma elaboração sistematizada de uma noção falsa da realidade. O construto, ao contrário do conceito, não é expressão da realidade e sim uma deformação da realidade. É por isso que nos construtos pode estar ausente a historicidade, a conexão com os demais aspectos da realidade etc." (Viana, 2007, p. 116). Ou seja, um construto é um falso conceito. Um conjunto de construtos interligados num sistema conformam uma ideologia. Pelo contrário, um conceito é uma
} 
A partir das contribuições de Raffestin (1993), o território passa a ser em grande medida confundido com espaço social, ou seja, o espaço como produto da ação humana sobre o próprio espaço. Não é nossa intenção aqui entrar na discussão do conceito de espaço, que exigiria para tanto, algumas dezenas de páginas. Mas o fato de Souza o desvincular, ou melhor, estabelecer com maior precisão as peculiaridades do território em relação ao espaço social, definindo aquele como relações de poder referenciadas no espaço, dá um avanço considerável no seu entendimento.

O problema reside em não ter compreendido que a relação poder/território é socialmente construída e conforma um tipo específico de território: os territórios autoritários. Para superar o fetichismo do poder, a primeira tarefa é identificá-lo. Creio já termos chegado a bom termo no entendimento da compreensão do fetichismo do poder. Para a construção do conceito de território, é necessário ir além do poder. É necessário identificar no bojo de relações sociais que desenrolam na sociedade e a conformam outras formas de relações. Bem entendido que a realidade presente é prenhe de relações vindouras, o ainda-não-existente Bloch (2005; 2006). Voltaremos a esta discussão mais à frente.

Apartemos, temporariamente, o território do poder. $O$ território é um conjunto de relações sociais concretas referenciadas espacialmente. Território e espaço só existem em inteira correlação, mas são distintos. As sociedades humanas sempre produziram seu espaço, pois só podem existir se espacializando, ou seja, produzir espaço é uma tendência natural das sociedades em geral. Da mesma forma, territorializar-se é uma necessidade humana. Desde tempos imemoriais que os seres humanos se referenciam no espaço, seja pela via do poder, seja pela via da solidariedade e igualdade concretas.

Para não nos afastarmos de nosso objetivo, analisemos de imediato alguns exemplos concretos que apresentaram aspectos da constituição de territórios libertários, ou seja, aqueles mediados por relações sociais que são antagônicas ao poder. Os territórios autoritários são por demais objeto de estudos (todos os autores citados até o momento que se dedicam à análise territorial se dedicam a compreendê-los). Já os territórios libertários são carentes de análises no que se refere aos estudos territoriais. Isto decorre, como já vimos, do fetichismo do poder. Os territórios libertários se 
constituem em momentos de contestação da sociedade capitalista. São uma tendência latente, um vir-a-ser que constantemente abala a ordem estabelecida. Procuraremos extrair seus aspectos fundamentais tomando como suporte de nossa investigação as várias experiências históricas desenvolvidas pelo proletariado quando constitui-se de classe em si a classe para si (Marx, s/d). Para utilizar uma terminologia mais precisa, quando passa de proletariado empírico, organizado pelo e para o capital, a proletariado revolucionário, quando organizado contra o capital e a favor da autogestão social.

A luta de classes é, desta maneira, conceito central na compreensão dos territórios libertários. A luta entre as classes sociais é sem sombra de dúvidas elemento fulcral na compreensão das relações sociais e territoriais estabelecidas. Qualquer análise que a prescinda cairá inevitavelmente em equívocos. Os territórios libertários: a) derivam da associação dos trabalhadores contra o capital; b) estas associações são por local de trabalho e moradia, ou seja, luta de classes na produção e nas demais esferas da sociedade; c) as relações internas no processo de construção dos territórios libertários se dão com base no coletivismo, solidariedade e igualdade concretas. Sem tais relações, é impossível qualquer forma de reação ao capital; d) no capitalismo, os territórios libertários apresentam-se como contra-poderes, ou seja, relações sociais igualitárias em luta contra as relações de poder dominantes; e) com a destruição do capitalismo, os territórios libertários se generalizam conformando a lógica territorial da sociedade autogerida.

Vejamos de maneira bem rápida, ponto por ponto.

a) Os territórios libertários são um produto da associação das classes trabalhadoras contra o capital.

Esta idéia leva a uma constatação fundamental: as classes dominantes não podem construir territórios libertários. As relações sociais fundadas na divisão de classes implicam em relações autoritárias, hierárquicas; é o ser, essência de tais relações. Desta maneira, o conjunto de elementos, processos, relações que dão origem às classes dominantes, conformando seus interesses particulares são antagônicos aos interesses das classes exploradas. Estas, por suas condições de vida, têm o interesse em eliminar as relações que as oprimem cotidianamente. Aquelas, pelo contrário, tem o interesse em mantê-las. Assim, os territórios libertários têm na associação do conjunto 
das classes oprimidas contra as classes dominantes sua determinação fundamental. Um território libertário só se constitui na luta contra a exploração e dominação.

b) O local de moradia e trabalho são os referenciais espaciais

Partimos do pressuposto de que a luta contra a exploração só pode ser realizada por aqueles que são submetidos a ela. A conquista da liberdade é um processo de dura luta efetivado por aqueles que a almejam. A liberdade não se conquista por representação. Nenhuma classe dominante tem o interesse em libertar uma classe subordinada e explorada. Deste modo, a emancipação é uma auto-emancipação. Somente os explorados e submetidos, se auto-organizando, podem almejar verdadeiramente o fim de sua exploração e submissão. Como diria Marx nos Estatutos da Associação Internacional dos Trabalhadores (conhecida como primeira Internacional), "A emancipação dos trabalhadores é obra dos próprios trabalhadores".

Este princípio será largamente desenvolvido por um conjunto de autores ligados ao marxismo nas primeiras décadas de século 20. Esta tendência ficou conhecida como Comunismo de Conselhos ou Conselhismo ${ }^{6}$. Expressando teoricamente toda a movimentação operária que se desenvolveu na Europa, como as revoluções russas de 1905 e 1917, a revolução alemã de 1918 a 1921, as rebeliões húngara e italiana de 1919 etc. bem como a guerra civil espanhola ocorrida entre 1936 e 1939, entre outros acontecimentos políticos de monta, os conselhistas desenvolveram um corpo conceitual teórico fundamental para a luta operária.

A idéia de auto-emancipação se concretiza na criação, por parte dos trabalhadores, dos conselhos operários. Estes são organizações por local de trabalho que expressam uma força contrária à lógica da exploração capitalista. Tais organizações são o oposto da lógica organizativa dominante. Os conselhos operários, via de regra, surgem inicialmente como comitês de greve, que se desenvolvem para reivindicar questões particulares (salários, melhores condições de trabalho etc.); destes comitês, formam-se organizações mais duradouras que excedem os limites iniciais e passam a reivindicar sua própria existência. Em momentos de radicalização da luta, estes comitês desenvolvem-se para conselhos operários que expressam a capacidade organizativa e de luta de toda uma fábrica. Com o desenvolvimento do processo de luta e sua conseqüente radicalização, este conselho de mero órgão de reivindicação, passa a ser um órgão de

\footnotetext{
${ }^{6}$ Para uma discussão aprofundada sobre esta tendência Cf. Authier (1975), Guillerm \& Bourdet (1975).
} 
gestão da produção, competindo ou suplantando a organização capitalista do processo de trabalho.

A tendência a generalizar-se para os demais espaços da vida dos trabalhadores é prática corrente nestes momentos. Assim, este princípio da autoorganização no local de trabalho se estende para a vida como um todo dos trabalhadores e invadem seus espaços de moradia, formando assim, as organizações por local de moradia. Um exemplo recente bem o demonstra. Trata-se do movimento "piquetero" na Argentina. Devido ao considerável número de desempregados e a miséria a que estavam e estão submetidos estes trabalhadores, começaram a criar organizações, não nos locais de trabalho, mas sim de moradia. Estas organizações, ao invés de organizarem os "piquetes" na porta ou dentro das fábricas, o faziam nas ruas e praças. Ou seja, o processo de auto-emancipação se dá onde a vida dos trabalhadores se desenvolve: local de trabalho e moradia.

c) A solidariedade, o coletivismo e a igualdade concreta são as relações fundamentais dos territórios libertários

Os territórios autoritários são fundados em relações de poder, tal como demonstramos. Os territórios libertários, pelo contrário, têm na solidariedade, coletivismo e igualdade concreta as determinações fundamentais de sua constituição. Isolados, os trabalhadores são impotentes perante ao capital e às demais forças dominantes (estado, partidos, sindicatos etc.). Só podem resistir quando organizados, quando associados. No processo de organização, a competição cede espaço à solidariedade. Na vida cotidiana, os trabalhadores competem entre si (por emprego, salário etc.). Quando em luta, deixam de competir, não por que querem, mas por que são impelidos pelo processo de luta a se solidarizarem, se assim não o fizerem são sumariamente destruídos. A solidariedade não é aqui um princípio moral, um ato de amor à moda dos religiosos e humanistas abstratos, mas sim uma necessidade prática de resistência ao poder.

Um outro aspecto que caracteriza os territórios libertários é o coletivismo. $\mathrm{O}$ coletivismo refere-se ao processo de organização interna e tomada de decisões. Num conselho, por local de moradia ou trabalho, as decisões devem e são sempre coletivas. Se não o forem, não pode ser designado como tal. Decisão coletiva significa participação ativa e consciente tanto na tomada das decisões quanto na execução das 
ações. O coletivismo, como princípio, é igualmente uma necessidade prática na luta dos trabalhadores, e portanto, na constituição dos territórios libertários. Tais territórios não podem reproduzir a hierarquia e dominação que existem nos territórios autoritários. Se assim o fizerem, o máximo que conseguem realizar é novamente a dominação e a exploração.

A decisão e a execução, portanto, para ser coletiva, tem de ser na mesma medida igualitária. Isto quer dizer que só pode participar do conselho os trabalhadores e aqueles que eles reconhecem como legítimos companheiros de luta. Dizemos igualdade concreta para se distinguir da igualdade abstrata que domina em nossa sociedade. Se todos são iguais perante a lei (igualdade abstrata) são desiguais na vida concreta. Igualdade concreta significa total ausência de privilégios dentro da organização, total ausência de hierarquizações derivadas de processos econômicos, políticos e intelectuais. Igualdade concreta é a igualdade verdadeira no poder de decisão e execução.

Vê-se com facilidade que os territórios libertários não têm nenhuma relação com os territórios autoritários. As relações sociais que lhes dão vida são antagônicas ao poder. Este funda-se na dominação; aquelas, na solidariedade, coletivismo e igualdade concreta. Os territórios libertários são desta maneira uma reação antagônica à sociedade capitalista. Neles encontram-se os germens que dão vida á sociedade autogerida, à sociedade futura. Entretanto, podem argumentar: os territórios libertários ainda reproduzem o poder, posto que impõem suas vontades aos territórios autoritários. A constituição dos territórios libertários implica na dominação dos territórios autoritários. Será assim mesmo?

\section{d) Os territórios libertários são formas de contra-poder}

Por falta de uma palavra melhor que expresse com maior clareza o conteúdo dos territórios libertários, utilizamos a expressão contra-poder. É necessário, entretanto, precisá-la com o maior rigor possível para que nossa interpretação não seja compreendida equivocadamente. Contra-poder não significa um poder contra outro poder. A palavra contra tem duas funções dentro do conjunto da expressão: a) expressa um sentido de negação: contra = não, ou seja, contra-poder seria um não-poder; b) significa que combate um poder existente. Contra-poder significa um conjunto de relações solidárias, coletivas e igualitárias em oposição a relações de poder dominantes. 
Este tipo de situação emerge em momentos de radicalização da luta revolucionária, momentos em que se constituem os territórios libertários. Comumente, a expressão "dualidade de poderes” é utilizada para designar tais momentos: Viana (2008) faz a seguinte observação:

$\mathrm{Na}$ verdade, não existe uma dualidade de "poderes", pois poder é uma relação de dominação que não existe no coso da autogestão operária. O que existe de fato é uma dualidade política, ou seja, de controle, onde o estado capitalista mantém o controle sobre a sociedade civil, numa relação de dominação, e os conselhos revolucionários exercem o controle das fábricas através da autogestão coletiva sem haver relação de dominação. A expressão "dualidade de poderes" é utilizada apenas para demarcar esta divisão entre controle da fábrica, empresas e bairros pela associação dos produtores, baseado na hegemonia operária, e o controle exercido pelo estado capitalista, baseado na dominação burguesa e, por seu caráter equivocado, substituímos por dualidade política, no qual a política revolucionária do proletariado se realiza na sociedade civil e a política conservadora se mantém no estado capitalista (Viana, 2008, p. 35).

Os territórios libertários são justamente estas áreas (bairros, regiões, cidades, fábricas etc.) nas quais a resistência e a luta dos trabalhadores auto-organizados se territorializam. Territorializar, desta maneira, não significa a referenciação de relações de poder num dado quadro espacial (Souza, 2003). Significa, pelo contrário, a referenciação espacial de relações igualitárias, coletivas e solidárias. Nos momentos de dualidade política, o contra-poder operário visa expandir seu conteúdo para territórios sempre mais amplos, aumentando assim os territórios libertários. O estado e as demais classes dominantes visam conter tal expansão, conservando os territórios autoritários. Os territórios libertários se constituem em oposição aos territórios autoritários. Nos momentos de dualidade política, quando os dois territórios expressam relações sociais distintas que se opõem, duas tendências se expressam: uma conservadora, que visa manter e reproduzir o status quo e outra revolucionária, que visa destruir o capitalismo e construir outra sociedade, que já tem seu embrião expresso nos territórios libertários.

e) Autogestão social: generalização dos territórios libertários

Se a dualidade política se resolver em favor das classes dominantes, há restabelecimento da dominação e por conseguinte dos territórios autoritários. Se pelo contrário, se resolve em favor dos trabalhadores, há a generalização dos territórios 
libertários e o estabelecimento da autogestão social. Não vamos aqui nos estender na descrição de minúcias de uma tal sociedade, que só existe hoje como tendência.

O que quero destacar é precisamente isto: a autogestão como tendência e os territórios libertários como sua dimensão espacial. Como diria Bloch (2005; 2006), a realidade presente é constituída também por processos de tendência, ou seja, por realidades que se apresentam, fugidias, para o futuro. A autogestão pode ser um grande absurdo para aqueles que têm a consciência fetichizada, mas para aqueles que conhecem os limites do fetichismo, ela se torna uma tendência concreta ou como diria Bloch, uma utopia concreta.

\section{Palavras finais}

Para encerrar esta reflexão sobre o fetichismo do poder e suas implicações na compreensão dos processos territoriais, destacamos que as pesquisas sobre territórios tem sua validade: desvendam em grande medida muitos problemas ligados à questão do território. O problema reside justamente em sua limitação: ter no conceito de poder um grande fetiche. Este fato impede que as pesquisas compreendam a verdadeiro caráter das relações territoriais, que podem ou não ser mediadas pelo poder.

As relações mediadas pelo poder conformam os territórios autoritários, estes são os territórios cotidianos de nossa vida na sociedade capitalista. Entretanto, em momentos específicos, tais territórios são questionados, são colocados em xeque pelo conjunto dos explorados. Quando tais questionamentos se dão, ou seja, quando há uma resistência operária ao poder capitalista, também se territorializam. A territorialização da resistência conforma os territórios libertários. O conteúdo destes é bastante distinto dos territórios autoritários. Durante a luta, a resistência auto-organizada, a solidariedade, o coletivismo e igualdade concreta suplantam as relações de poder.

Podemos dizer que a construção de territórios é algo intrínseco ao ser humano. Pelo contrário, o poder é uma relação social de dominação, que pode e deve ser abolida. A formação de conselhos, formas de auto-organização de trabalhadores (por local de moradia ou trabalho), demonstra que existe uma tendência em nossa sociedade a suprimir os territórios autoritários. Por isto é necessário compreender que território e 
poder não são irmãos siameses, que nasceram unidos pelas vísceras e vão morrer assim. A vinculação entre poder e território é histórica e socialmente determinada.

O primeiro passo para superar o entendimento de que o poder não é intrínseco ao território, é superar o fetichismo do poder. Superar o fetichismo do poder não basta, igualmente. É necessário compreender o conteúdo dos territórios libertários e autoritários, identificando assim as diferenças que os separam. Por último, é fundamental se posicionar e defender com clareza qual tendência se quer afirmar: a que fetichiza o poder, tornando-o perene, ou a que o historiciza e almeja seu fim.

\section{Referências}

AUTHIER, Denis. Para a história do movimento comunista na Alemanha de 1918 1921. In: Denis Authier (org.). A esquerda alemã (1918-1921). Porto: Afrontamento, 1975.

BLOCH, Ernst. O princípio Esperança. V. 1. Rio de Janeiro: Contraponto/Ed. Uerj, 2005.

O princípio Esperança. V. 2. Rio de Janeiro: Contraponto/Ed. Uerj, 2006.

FOUCAULT, Michel. Vigiar e Punir: História da Violência nas Prisões. Petrópolis: Vozes, 1983.

GOMES, Paulo César da Costa. Geografia e Modernidade. Rio de Janeiro: Bertrand Brasil, 1996.

MARX, Karl. O Capital: Crítica da Economia Política. Volume 1. Tomo 1: O Processo de Produção do Capital. São Paulo: Nova Cultural, 1988.

Miséria da Filosofia. São Paulo: Exposição do Livro, s/d.

MORAES, Antônio Carlos Robert. Geografia: Pequena História Crítica. São Paulo: HUCITEC, 1988.

MOREIRA, Ruy. O Que é Geografia. São Paulo: Brasiliense, 1992.

RAFFESTIN, Claude. Por Uma Geografia do Poder. São Paulo: Brasiliense, 1993.

RATZEL, Friedrich. Antropogeografia: Geografia do Homem. In: MORAES, Antônio Carlos Robert (org.). Ratzel: Geografia. São Paulo: Ática, 1990.

SAQUET, Marcos Aurélio. Abordagens e Concepções de Território. São Paulo: Expressão Popular, 2007.

SODRÉ, Nelson Werneck. Introdução à Geografia: Geografia e Ideologia. Petrópolis: Vozes, 1986. 
SOUZA, Marcelo Lopes de. O Território: Sobre Espaço e Poder, Autonomia e Desenvolvimento. In: CASTRO, Iná Elia de. Et al: Geografia: Conceitos e Temas. Rio de Janeiro: Bertrand Brasil, 2003.

A Antropogeografia de Ratzel: Indicações. In: (org.). Ratzel: Geografia. São Paulo: Ática, 1990.

VASQUEZ, Adolfo Sanches. Ética. Rio de Janeiro: Civilização Brasileira, 1975.

VIANA, Nildo. Estado, Democracia e Cidadania: A Dinâmica da Política Institucional no Capitalismo. Rio de Janeiro: Achiamé, 2003.

Os Valores na Sociedade Moderna. Brasília: Thesaurus, 2007.

Recebido para publicação em novembro de 2009

Aprovado para publicação em fevereiro de 2010 